ҚАЗАҚСТАН РЕСПУБЛИКАСЫ

ҰЛТТЫҚ ҒЫЛЫМ АКАДЕМИЯСЫНЫН

АБАЙ АТЫНДАҒЫ ҚАЗАҚ ҰЛТТЫҚ

ПЕДАГОГИКАЛЫҚ УНИВЕРСИТЕТІНІҢ

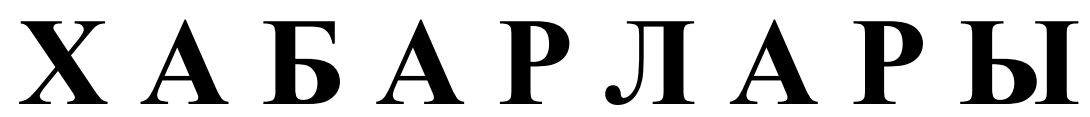

\section{ИЗВЕСТИЯ}

НАЦИОНАЛЬНОЙ АКАДЕМИИ НАУК РЕСПУБЛИКИ КАЗАХСТАН

КАЗАХСКИЙ НАЦИОНАЛЬНЫЙ

ПЕДАГОГИЧЕСКИЙ УНИВЕРСИТЕТ ИМ. АБАЯ

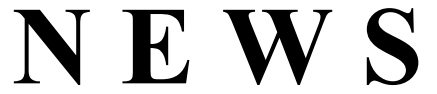

OF THE NATIONAL ACADEMY OF SCIENCES OF THE REPUBLIC OF KAZAKHSTAN

ABAY KAZAKH NATIONAL PEDAGOGICAL UNIVERSITY

ҚОҒАМДЫҚ ЖӘНЕ ГУМАНИТАРЛЫҚ ҒЫЛЫМДАР СЕРИЯСЫ

СЕРИЯ ОБЩЕСТВЕННЫХ И ГУМАНИТАРНЫХ НАУК

SERIES OF SOCIAL AND HUMAN SCIENCES

\author{
6 (322) \\ ҚАРАША - ЖЕЛТОҚСАН 2018 ж. \\ НОЯБРЬ - ДЕКАБРЬ 2018 Г. \\ NOVEMBER - DECEMBER 2018 \\ ИЗДАЕТСЯ С ЯНВАРЯ 1962 ГОДА \\ PUBLISHED SINCE JANUARY 1962 \\ ЖЫЛЫНА 6 РЕТ ШЫҒАДЫ \\ ВЫХОДИТ 6 РАЗ В ГОД \\ PUBLISHED 6 TIMES A YEAR
}

1962 ЖЫЛДЫҢ ҚАНТАР АЙЫНАН ШЫҒА БАСТАҒАН 
Ба с ре дактор

ҚР ҰҒА кұрметті мүшесі

Балықбаев Т.O.

Р е д а ц и я а лқ а сы:

экон. ғ. докторы, проф., ҚР ҰҒА академигі Баймұратов У.Б.; тарих ғ. докторы, проф., ҚР ҰҒА академигі Байпақов К.М.; филос. ғ.докторы, проф., ҚР ҰҒА академигі Есім Г.Е.; фил. ғ. докторы,, проф., ҚР ҰҒА академигі Қирабаев С.С.; эк. ғ. докторы, проф., ҚР ҰҒА академигі Кошанов А.К.; эк.ғ. докторы, проф., ҚР ҰҒА академигі Нәрібаев К.Н. (бас редактордың орынбасары); филос. ғ.докторы, проф., ҚР ҰҒА академигі Нысанбаев А.Н.; заң ғ. докторы, проф., ҚР ҰҒА академигі Сәбікенов С.Н.; заң ғ. докторы, проф., ҚР ҰҒА академигі Сүлейменов М.К.; эк. ғ. докторы, проф., ҚР ҰҒА академигі Сатыбалдин С.С.; тарих ғ. докторы, проф., ҚР ҰҒА академик Әбжанов Х.М.; тарих ғ. докторы, проф., ҚР ҰҒА корр. мүшесі Әбусеитова М.Х.; тарих ғ. докторы, проф., ҚР ҰҒА академик Байтанаев Б.А.; филол. ғ. докторы, проф., ҚР ҰҒА корр. мүшесі Жақып Б.А.; фил. ғ. докторы, проф., академик НАН РК Қалижанов У.К.; филол. ғ. докторы, проф., ҚР ҰҒА академик Қамзабекұлы Д.; тарих ғ. докторы, проф., ҚР ҰҒА академик Қожамжарова Д.П.; тарих ғ. докторы, проф., ҚР ҰҒА академик Койгелдиев М.К.; фил. ғ. докторы, проф., ҚР ҰҒА корр. мүшесі Кұрманбайұлы Ш.; тарих ғ. докторы, проф., ҚР ҰҒА корр. мүшесі Таймағанбетов Ж.К.; социол. ғ. докторы, проф., ҚР ҰҒА корр. мүшесі Шәукенова 3.К.; фил. ғ. докторы, проф., КР ҰҒА корр. мүшесі Дербісәлі А.; саяси. ғ. докторы, проф., Бижанов А.К., тарих ғ. докторы, проф., Кабульдинов 3.Е.; фил. ғ. докторы, проф., ҚР ҰҒА корр мүшесі Қажыбек Е.3.

\section{Р едакция ке н е с i:}

Молдова Республикасының ҰҒА академигі Белостечник Г. (Молдова); Әзірбайжан ҰҒА академигі Велиханлы Н. (Азербайджан); Тәжікстан ҰҒА академигі Назаров Т.Н. (Тәжікстан); Молдова Республикасының ҰҒА академигі Рошка А. (Молдова); Молдова Республикасының ҰҒА академигі Руснак Г. (Молдова); Әзірбайжан ҰҒА корр. мүшесі Мурадов Ш. (Әзірбайжан); Әзірбайжан ҰҒА корр. мүшесі Сафарова 3. (Әзірбайжан); э. ғ. д., проф. Василенко В.Н. (Украина); заң ғ. докт., проф. Устименко В.А. (Украина)

«Қазақстан Республикасы Ұлттық ғылым академиясының Хабарлары. Қоғамдық және гуманитарлық ғылымдар сериясы». ISSN 2224-5294

Меншіктенуші: «Қазақстан Республикасының Ұлттық ғылым академиясы» РҚБ (Алматы қ.)

Қазақстан республикасының Мәдениет пен ақпарат министрлігінің Ақпарат және мұрағат комитетінде 30.04.2010 ж. берілген № 10894-Ж мерзімдік басылым тіркеуіне қойылу туралы куәлік

Мерзімділігі: жылына 6 рет.

Тиражы: 500 дана.

Редакцияның мекенжайы: 050010, Алматы қ., Шевченко көш., 28, 219 бөл., 220, тел.: 272-13-19, 272-13-18, http://nauka-nanrk.kz. social-human.kz

(C) Қазақстан Республикасының Ұлттық ғылым академиясы, 2018

Типографияның мекенжайы: «Аруна» ЖК, Алматы қ., Муратбаева көш., 75. 
Главный редактор

Почетный член НАН РК

T.O. Балыкбаев

Р е дак ци онн а я коллег и я:

докт. экон. Н., проф., академик НАН РК У.Б. Баймуратов; докт. ист. н., проф., академик НАН РК К.М. Байпаков; докт. филос. Н., проф., академик НАН РК Г.Е. Есим; докт. фил. Н., проф., академик НАН РК С.С. Кирабаев; докт. экон. Н., проф., академик НАН РК А.К. Кошанов; докт. экон. Н., проф., академик НАН РК К.Н. Нарибаев (заместитель главного редактора); докт. филос. н., проф., академик НАН РК А.Н. Нысанбаев; докт. юр. Н., проф., академик НАН РК С.Н. Сабикенов; докт. юр. н., проф., академик НАН РК М.К. Сулейменов; докт. экон. Н., проф., академик НАН РК С.С. Сатубалдин; докт. ист. н., проф., академик НАН РК Х.М. Абжанов; докт. ист. н., проф., чл.-корр. НАН РК М.Х. Абусеитова; докт. ист. н., проф., академик НАН РК Б.А. Байтанаев; докт. фил. н., проф., чл.-корр. НАН РК Б.А. Жакып; докт. фиолол. н., проф., академик НАН РК У.К. Калижанов; докт. фил. н., проф., академик НАН РК Д. Камзабекулы; докт. ист. н., проф., академик НАН РК Д.П. Кожамжарова; докт. ист. н., проф., академик НАН РК М.К. Койгельдиев; докт. филол. н., проф., чл.-корр. НАН РК Ш. Курманбайулы; докт. ист. н., проф., чл.корр. НАН РК Ж.К. Таймаганбетов; докт. социол. н., проф., чл.-корр. НАН РК З.К. Шаукенова; д. филол. н., проф., чл.-корр. НАН РК А. Дербисали; доктор политических наук, проф., Бижанов А.К.; доктор ист. наук, проф., Кабульдинов 3.Е.; доктор филол. н., проф., член-корр. НАН РК Қажыбек Е.3.

Р е дак ци онны й с ов ет

академик НАН Республики Молдова Г. Белостечник (Молдова); академик НАН Азербайджанской Республики Н. Велиханлы (Азербайджан); академик НАН Республики Таджикистан Т.Н. Назаров (Таджикистан); академик НАН Республики Молдова А. Рошка (Молдова); академик НАН Республики Молдова Г. Руснак (Молдова); чл.-корр. НАН Азербайджанской Республики Ш. Мурадов (Азербайджан), член-корр. НАН Азербайджанской Республики 3.Сафарова (Азербайджан); д. э. н., проф. В.Н. Василенко (Украина); д.ю.н., проф. В.А. Устименко (Украина)

Известия Национальной академии наук Республики Казахстан. Серия общественных и гуманитарных наук. ISSN 2224-5294

Собственник: РОО «Национальная академия наук Республики Казахстан» (г. Алматы)

Свидетельство о постановке на учет периодического печатного издания в Комитете информации и архивов

Министерства культуры и информации Республики Казахстан № 10894-Ж, выданное 30.04.2010 г.

Периодичность 6 раз в год

Тираж: 500 экземпляров

Адрес редакции: 050010, г. Алматы, ул. Шевченко, 28, ком. 219, 220, тел. 272-13-19, 272-13-18, www:nauka-nanrk.kz / social-human.kz

(C) Национальная академия наук Республики Казахстан, 2018 г.

Адрес типографии: ИП «Аруна», г. Алматы, ул. Муратбаева, 75

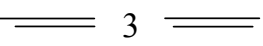


Chief Editor

\section{Honorary member of NAS RK \\ Balykbayev T.O}

Editorial board:

Doctor of economics, prof, academician of NAS RK Baimuratov U.B.; doctor of history, prof, academician of NAS RK Baipakov K.M.; doctor of philosophy, prof, academician of NAS RK Esim G.E.; doctor of philology, prof, academician of NAS RK Kirabayev S.S.; doctor of economics, prof, academician of NAS RK Koshanov A.K.; doctor of economics, prof, academician of NAS RK Naribayev K.N. (deputy editor-in-chief); doctor of philosophy, prof, academician of NAS RK Nyssanbayev A.N.; doctor of law, prof, academician of NAS RK Sabikenov S.N.; doctor of law, prof, academician of NAS RK Suleymenov M.K.; doctor of economy, prof, academician of NAS RK Satybaldin S.S.; doctor of history, prof, academician of NAS RK Abzhanov H.M; doctor of history, prof, corresponding member of NAS RK Abuseitova M.H.; doctor of history, prof, academician of NAS RK Baitanaev B.A.; doctor of philology, prof, corresponding member of NAS RK Zhakyp B.A.; doctor of philology, prof, academician of NAS RK Kalizhanov U.K.; doctor of philology, prof, academician of NAS RK Hamzabekuly D.; doctor of history, prof, academician of NAS RK Kozhamzharova D.P.; doctor of history, prof, academician of NAS RK Koigeldiev M.K.; doctor of philology, prof, corresponding member of NAS RK Kurmanbaiuly Sh.; doctor of history, prof, academician of NAS RK Taimaganbetov J.K.; doctor of sociology, prof, corresponding member of NAS RK Shaukenova Z.K.; doctor of philology, prof, corresponding member of NAS RK Derbisali A.; doctor of political science, prof Bizhanov A.K; doctor of History, prof Kabuldinov Z.E.; doctor of philology, prof, corresponding member of NAS RK Kazhybek E.Z.

\section{Editorial staff:}

Academician NAS Republic of Moldova Belostechnik.G (Moldova); Academician NAS Republic of Azerbaijan Velikhanli N. (Azerbaijan); Academician NAS Republic of Tajikistan Nazarov T.N. (Tajikistan); Academician NAS Republic of Moldova Roshka A. (Moldova) Academician NAS Republic of Moldova Rusnak G. (Moldova); Corresponding member of the NAS Republic of Azerbaijan Muradov Sh. (Azerbaijan); Corresponding member of the NAS Republic of Azerbaijan Safarova Z. (Azerbaijan); Associate professor of Economics Vasilenko V.N. (Ukraine), Associate professor of Law Ustimenko V.A. (Ukraine)

News of the National Academy of Sciences of the Republic of Kazakhstan. Series of Social and Humanities. ISSN 2224-5294

Owner: RPA "National Academy of Sciences of the Republic of Kazakhstan" (Almaty)

The certificate of registration of a periodic printed publication in the Committee of information and archives of the Ministry of culture and information of the Republic of Kazakhstan N 10894-Ж, issued 30.04.2010

Periodicity: 6 times a year

Circulation: 500 copies

Editorial address: 28, Shevchenko str., of. 219, 220, Almaty, 050010, tel. 272-13-19, 272-13-18, www:nauka-nanrk.kz / social-human.kz

(C) National Academy of Sciences of the Republic of Kazakhstan, 2018

Address of printing house: ST "Aruna", 75, Muratbayev str, Almaty 
N E W S

OF THE NATIONAL ACADEMY OF SCIENCES OF THE REPUBLIC OF KAZAKHSTAN SERIES OF SOCIAL AND HUMAN SCIENCES

ISSN 2224-5294

Volume 6, Number 322 (2018), 42 - 50

https://doi.org/10.32014/2018.2224-5294.34

\author{
A.A. Karabalina ${ }^{1}$, A.B. Alsitova ${ }^{2}$, Zh.N. Kereimaganbetova ${ }^{1}$, N.M. Abisheva ${ }^{3}$ \\ ${ }^{1}$ K. Zhubanov Aktobe Regional State University, Aktobe; \\ ${ }^{2}$ Baishev University, Aktobe, Kazakhstan; \\ ${ }^{3}$ JSC "National Center for professional development "Orleu", Aktobe, Kazakhstan \\ Aksaule2011@mail.ru, assemgul_87@,mail.ru, zhanar-kn@mail.ru,nurgulabisheva@mail.ru
}

\title{
THE VALUES AS CRITICAL FACTOR OF MORAL EDUCATION
}

\begin{abstract}
The education system of the Republic of Kazakhstan is facing severe reforms. One of the main problems of problems is the spiritual and moral education of the young. One of the possible reasons of this problem is the change of ideological orientations, the spiritual vacuum as a result of the collapse of USSR (penetration of the culture of violence, egoism, deception, Western commercial culture, etc.) into the national culture. The lack of spirituality, low morality, as well as rudeness, crime, drug addiction, alcoholism and many other evils of our time they all destroy both a person, society, and the state. It is necessary to clarify at once that at present the theoretical elaborations of the concepts of "spirituality", "morality", "emotional and moral feelings" are often characterized by ambiguity and inconsistency. In the complex contemporary reality, in the flow of the media, which do not always have a positive impact on the formation of the necessary moral qualities, it becomes more and more difficult for the younger generation to figure out what is right for him and what is false.
\end{abstract}

Key word: spiritual and moral education, morality, moral qualities, moral values of the personality.

In the Republic of Kazakhstan, a "Concept of education in the system of continuous education" is one of primarly first State Program. "The problems of education development undoubtedly deserve close attention, since we are talking about tomorrow of Kazakhstan, the value orientations of our society, the national security of the country, whose roots lie in upbringing, creative development, and public development of the younger generation. The development of education in the education system of the Republic of Kazakhstan in recent years has rightfully become one of the priorities in the activities of the Ministry of Education and Science of the Republic of Kazakhstan, education authorities of subjects, educational institutions of all types and types " [1]. Spiritual, moral and patriotic education is an aim of the strategic development program of Kazakhstan - "Kazakhstan-2030", "Five Institutional Reforms," "Rukhany Zhangyru."

Our views on the essence of the basic concepts and factors of the development of spiritual and moral education rely on critical concepts for the search for new ideas. Critical concepts of moral education are "morality," "moral qualities," "moral values of the person."

"Value" is defined as the importance, significance, benefit, utility of something. Externally, the value acts as a property of the object or phenomenon. However, significance and usefulness are inherent not in nature, not merely because of the internal structure of the object itself, but as subjective assessments of specific properties that are involved in the sphere of human social life, a person is interested in them or needs. The system of values plays the role of everyday orientations in the subject and social reality of a person, the designations of his various practical attitudes towards the surrounding objects and phenomena.

The norms that have taken shape in society are the highest expression of the value system (that is, the prevailing ideas about what is considered good, right, or desirable). The concept of values and norms differ. Values - these are abstract, general concepts, and norms - these are rules or guidelines for behavior in certain situations. The system of values prevailing in society plays a vital role since it affects the content of norms. All norms reflect social values. The system of values can show the norms prevailing in society.

Moral values are the most critical element of the internal structure of personality, which provides and shows the degree of its maturity and sociality, determines the very essence of a social individual, the state 
of development of the inner world of a person, his mind, character, consciousness, conscience, soul, characterizes his level of humanity.

According to Soviet philosophers the categorical apparatus, which includes the concept of "value", "value relation", "assessment", "value orientation" appeals attention to the educational aspect of the theory of values, that education implies the awareness of the educated person of specific phenomena as values or non-values, determined by his understanding of the totality of values. [2]

Values are defined in philosophy as "specifically social definitions of objects of the surrounding world, revealing their positive or negative significance for man and society (good, good, evil, beautiful, enclosed in phenomena of social life and nature). [3]

The values include only "positively significant events and phenomena related to social progress. [4] V. P. Tugarinov defines values as "objects, phenomena and their properties that are necessary (necessary, useful, accepted, etc.) to people of a specific society or class and individual personality as means of satisfying needs and interests. [5]

Values are not primary. S. L. Rubinstein emphasizes that values are the special form of reflection, the product from the relationship between the world and human, expressing what is in the world, including what human creates in the process of history, is significant for him. [6]

The integrative role of value orientations is noted by researchers such as A.G. Zdravomyslov and V.A. Yadov, which believe that value orientations are "this component of the structure of the personal consciousness, which represents a certain axis of consciousness, around which the personal thoughts and feelings revolve and from the point of view of which many life questions are solved" [7] .

The system of value orientations determines the content direction of the personality and forms the basis of its relationship to the world, to other people, to itself, the basis of the worldview and the core of life motivation, the basis of the life concept and "philosophy of life."

Sh. Schwartz and W. Bilski hypothesized the existence of a bound - a small number of "universal motivational types" - "before - men, "differing from each other by" type of goal "or dominant - the growing value. They identified ten such "domains," which represent various types of value orientations of the individual. Each "domain" corresponds to one or another leading terminal value - self-regulation, the fullness of sensations, hedonism, achievement of success, power, security, conformance, maintenance of traditions, group welfare, the well-being of all people in general. Proceeding from this, Sh. Schwartz and W. Bilski distinguish the following dichotomy of values:

$\checkmark$ Values of conservation (security, conformity, traditions) -the value of change (fullness of sensations, self-regulation).

$\checkmark$ Values of self-determination (group well-being and human - society in general) - the human values (power, achievement, hedonism) [8].

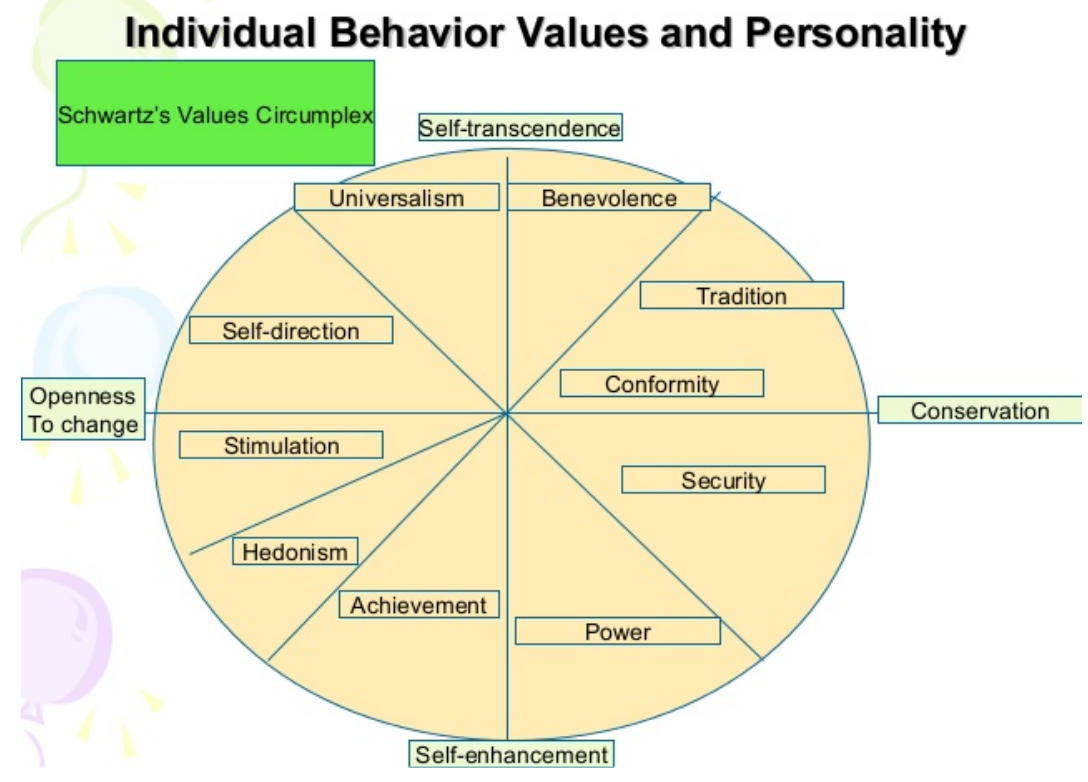

Figure 1 - Schwart's Values Theory 
As noted D. A. Leontiev, the individual values hierarchy, as a rule, is a sequence of the - effectiveness of reasonably well-demarcated "blocks." Leontiev grouped the values, combined into polar block systems [9].

Terminal values opposition include:

- Specific life values (health, work, friends, family life) - abstract values (knowledge, development tie, freedom, creativity).

- Values of professional self-realization (interest -work, productive life, creativity, active life) - the values of personal life (health, love, having friends, entertainment, family life).

- Individual values (health, creativity, freedom, active life, entertainment, self-confidence, financially secured life) - interpersonal values (having friends, a happy family life, the other's happiness).

- Active values (freedom, active life, productive life, exciting work) - passive values (the beauty of nature and art, self-confidence, knowledge, life- wisdom).

Among the instrumental values of D. A. Leontiev, - are following dichotomies:

- Ethical values (honesty, zero tolerance to crime) - values of interpersonal communication (upbringing, cheerfulness, sensitivity) - values of professional self-realization (responsibility, efficiency in business, strong will, diligence).

- Individualistic values (high demands, - dependence, strong will) - conformist values (pilar, selfcontrol, responsibility) - altruistic -values (tolerance, sensitivity, open-mindedness).

- Values of assertiveness (high demands, independence, intransigence, courage, strong will) - values adoption of others (tolerance, sensitivity, open-mindedness).

- Intellectual values (education, rationalism, self-control) emotional attitude values (cheerfulness, honesty, sensitivity).

Bulgarian researcher V. Momov contrasts - target values (or conceivable - desired, possible) and existing values (or cash - relevant). According to Momov values could be classified as target value, goalvalue, ideals, desire-values, and proper values (normative values). [10].

In the theory of A. Maslow, in contrast to the typological approach of S. Schwartz and W. Bilski, the value groups (as well as the blocks forms) form a vertical hierarchy. According to him, by - needs and values "are not a dichotomy, but a consistent hierarchy, that is, they depend on each other" [11] . A. Maslow identifies two main groups of values:

- B-values (values of life) - the highest values of self-actualizing people (truth, goodness, beauty, integrity, overcoming of dichotomy, vitality, uniqueness, perfection, fullness, justice, order, simplicity, lay down - bone without effort, etc.);

- D-values (deficient values) - lower values, which are the result of frustrated needs (peace, rest, sleep, rest, dependence, security, etc. ) [12].

Maslow's Hierarchy of Needs (original five-stage model)

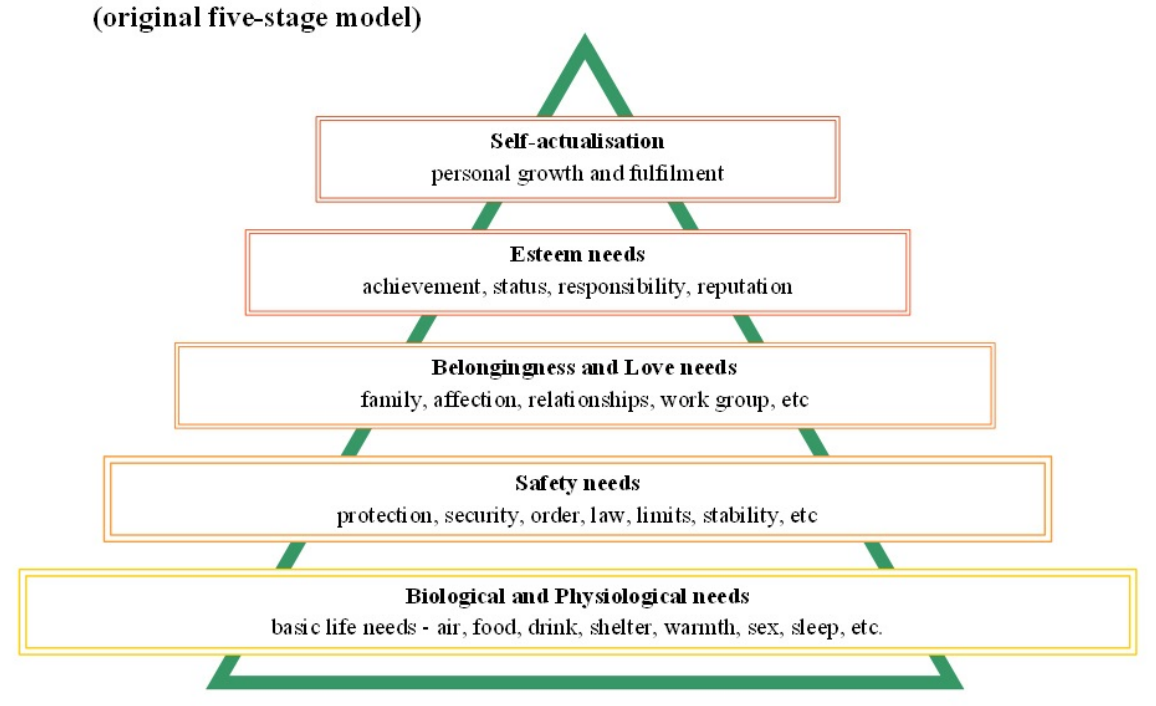

Figure 2 - Maslow's Hierarchy of Needs 
As well as A. Maslow, the theory motivations K. Alderfer developed by definition of human wants. The distinctive feature of this theory is the combination of requirements in three groups:

- the needs for existence (on Maslow's classification requirements physiological and in safety);

- the requirements connected with human social nature (the need for social interaction);

- requirements for personal growth and development.

As a result of the generalization of typical situations that society or humanity had to face in history, V. Frankl identifies three groups of eternal values - semantic universals:

- values of creativity, allowing a person to realize that he gives to society;

- values of experience, allowing a person to realize that he takes from society;

- values of a relationship allowing a person to realize by - the position he occupies concerning factors limiting - living his life.

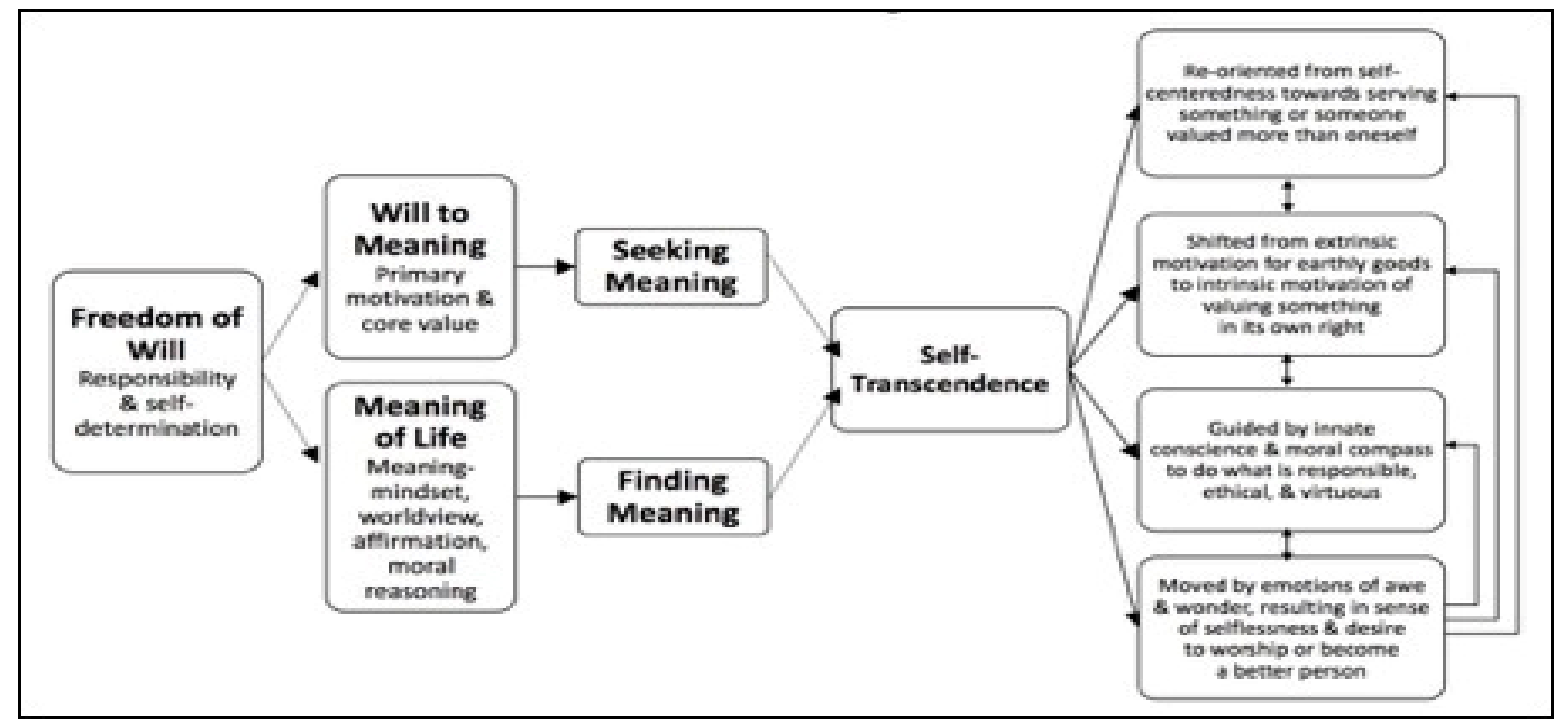

Figure 3 - V. Frankl theory of values

Values of the relationship, in turn, are divided into three - categories: meaningful attitude to pain, guilt, and death. [13]

M. Rokich proposed a theoretical model for studying the value orientations of a person and presented a useful tool for measuring them[14].

In the latter case, value orientations act as an individual ideology of lifestyle. They are formed in the assimilation of social experience and manifest themselves in the goals, ideas, beliefs, interests, and other elements of the inner world, are realized in the behavior of the individual. In the structure of activity, value orientations are closely related to the cognitive and volitional sides; they ensure the stability of the individual, the continuity of a specific type of behavior. The system of value orientations is the content side of the orientation of the individual and reflects the internal basis of its relationship to reality.

Value orientations are a complex formation in which three main components are: cognitive, emotive, and behavioral. Cognitive is an element of knowledge, emotive - the emotional component, resulting from the assessment; behavioral - associated with the implementation of value orientations in the behavior of the individual.

Value orientations are among the most critical components of the personality structure; according to the degree of their formation, one can judge the level of personality development. Developed value orientations are a sign of maturity, an indicator of a measure of sociality. A stable and consistent set of value orientations determines such personal qualities as integrity, reliability, loyalty to certain principles and ideas, the ability to make strong-willed efforts in the name of these ideas and values, the activity of life position. The inconsistency of value orientations generates inconsistency in behavior. Underdevelopment of value orientations is a sign of infantilism, domination of external stimuli in the internal structure of the personality. 
Scientists have proposed many typologies of values, the most well-known is the division into spiritual, social and material. Besides, they highlight the values corresponding to different areas of social life (moral, aesthetic, political, educational, economic, etc.). M. Rokich cites his typology:

- Values-goals (terminal), defined by them as a person's beliefs that the ultimate goal of individual existence is worth striving for it. Terminal values determine for a person the meaning of his life, indicate that it is especially important and significant for him.

- Values-means (instrumental), defined as the beliefs of the person that a specific course of action or personality trait are preferred in any situation.

Instrumental values are divided into groups:

- ethical, communication values, business values;

- individualistic, conformist, altruistic;

- self-affirmation, acceptance of other people, etc. [15]

The values represent all significant meanings for a person, but the most global of them is the meaning of life, the essence of which lies in the relationship of the individual to himself and society, to understand his place in society and to understanding the social significance of his activities. This or that understanding [16] the meaning of life determines the whole line of human behavior and is the moral core on which his moral attitudes are "fixed." The "meaning of life" is commonly understood as people's awareness of the main content of all activities (past, present, future), which determines their place and significance in the life of society.

It is necessary for a person to be sure that an individual life is necessary for him, for people, and for society. The correct understanding of the meaning of life by a person gives him such moral strength, which helps in overcoming life's difficulties. For a person, it is of interest not only the result of his activity but also the activity itself, the need for it.

According to A.I. Titarenko, value orientations are such elements of moral consciousness that are reproduced, objectified in actions and relationships [17]. This feature of value orientations is noted by researchers such as D.N. Uznadze, S.L. Rubinstein, V.N. Myasishchev, G.Kh. Shingarov, who were among the first to turn to the study of this phenomenon, which is described in psychology through the notions of "attitude," "social orientation," and "attitude. "The structural elements of moral consciousness are organically included in the composition of the motives and incentives of all types and forms of activity of subjects, determining its orientation.

V.A. Yadov mentioned that the inclusion of value orientations in the structure of moral consciousness "allows one to catch the most common social determinants of behavioral motivation, the sources of which should be sought in the socio-economic nature of society and the environment in which a person was formed and where the daily life activity of a person takes place" [18]. By assimilating the values of his environment and turning them into value orientations, the motivational forces of his behavior, a person becomes an active subject of social activity.

Thus, values and value orientations can be represented as fundamental elements of moral consciousness, connecting not only elements of theoretical moral consciousness, but also ordinary ones, since the boundary between these two levels is very mobile, and such structural elements as assessments and norms, as well as the values themselves, can be formed both spontaneously (at the level of everyday consciousness) and developed consciously (at the theoretical level in a systematic and logical evidencebased form).

The value is usually understood as an object, a phenomenon of the material or spiritual culture of humanity, which has acquired a stable meaning for an individual since it serves or could serve as a means of satisfying its needs and achieving its main goals. [19]. J. Hudeček gives a short but very capacious definition of this phenomenon: "Values are a part of the individual's consciousness, while that part of it, without which there is no personality" [20].

Modern researchers in two guises interpret the concept of "moral value":

- first, it is the moral norms, principles, ideas, the concepts of good and evil, justice, and happiness that are objectively existing, formed by concrete historical and social experience of humanity;

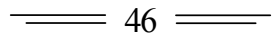


- secondly, the moral value can act as a personal phenomenon, as a personified person's attitude to social, moral values, their acceptance, rejection, etc.

Moral values, among other values, are many researchers (V. Blumkin, D. A. Leontyev, T. I. Porohovskaya, A. I. Titarenko, and others) put it on the list of the highest.

So what is "moral value"? By this phenomenon, we understand the integral formation of moral consciousness, which includes moral norms, evaluations, concepts, principles, ideals, closely related to the motives and needs of the individual, ensuring the focus of his consciousness on the achievement of higher moral goals, performing the functions of evaluation, regulation of human behavior on basis of good and evil.

Morality is a component of a culture whose content is the ethical values that form the basis of consciousness. Morality is the ability of a person to act, think and feel by his spiritual principle, these are the ways and methods of transmission to the outside of his inner spiritual world. The process of spiritual and moral education is a set of consistent interactions of the educator and the team, aimed at achieving the effectiveness and quality of pedagogical activity and the proper level of moral education of the personality of the adolescent.

Morality is an integral part of an integrated approach to the education of the individual "The formation of morality is nothing but the translation of moral norms, rules, and requirements into knowledge, skills, and habits of personal behavior and their unswerving observance," writes I.F. Harlamov. Morality is formed from the word "morals." In Latin, manners sound like morass - morality. [21].

Morals are those standards and norms that guide people in their behavior, in their daily actions. Morals are not eternal and not immutable categories. They are reproduced by the power of the habits of the masses, supported by the authority of public opinion, and not of legal provisions. At the same time, moral requirements, norms, and rights receive a specific justification in the form of ideas about how to behave in society.

Moral norms - is an expression of certain relations, prescribed by the morality of society to the behavior and activities of the individual in various fields.

The formation of moral values is influenced by public life. According to many psychologists, there is currently a severe deformation of moral values under the influence of Western culture. E. Fromm argued that the change of the social system changes the personal consciousness, the meaning of human life [22]. If Shakespeare's Hamlet asked: "To be or not to be?", Then the modern man changes the wording of the question to "To be or Have." The desire for enrichment, pragmatism gives birth to a certain emptiness in the human soul. Thus, Western culture, which has become widespread at present, requires the formation of a "market" type of personality. Its values are individualism, self-orientation, the family as a "public" institution loses its value.

\begin{tabular}{|ccc|}
\hline SUMMARY OF FROMM'S HUMAN NEEDS \\
\hline & $\begin{array}{c}\text { NEGATIVE } \\
\text { COMPONENTS }\end{array}$ & $\begin{array}{c}\text { POSITIVE } \\
\text { COMPONENTS }\end{array}$ \\
\hline Relatedness & $\begin{array}{c}\text { Submission/ } \\
\text { domination }\end{array}$ & Love \\
\hline Transcendence & Destructiveness & Creativeness \\
\hline $\begin{array}{c}\text { Sootedness } \\
\text { identity }\end{array}$ & Fixation & Wholeness \\
\hline $\begin{array}{c}\text { Frame of } \\
\text { Orientation }\end{array}$ & Irrational goals & Rational goals \\
\hline
\end{tabular}

Figure 4 - Erich Fromm's human needs and values

Another problem is propaganda in the media, in which such values as "family," "marriage" and "love" are distorted, and are demonstrated in some surrealism. 
Education is one of the main categories of pedagogy related to the purposeful activity of teachers to develop the professional and personal qualities of students, contributing to their entry into modern culture, as well as stimulating self-development and their development as subjects of their own lives. The goals of education are the expected changes in a person, carried out under the influence of specially prepared and systematically conducted educational actions and actions. The specificity of education is revealed in the fact that it is addressed to the whole person and can only be understood by the logic of its qualitative changes.

There are three aspects of education in the opinion of N. M. Borytko : social (identification with a socio-cultural and professional environment; acceptance of values, in the first place); individual (isolation of oneself from the environment: self-determination, self-establishment, self-realization, etc.); communicative (interaction with the environment: the exchange of influences, not only the acceptance of the values of the environment, but also the statement in it of their views, their value) [23] .

The educational system is an ordered, basic set of components, the interaction and integration of which determines the ability of an educational institution or its structural subdivision to purposefully and effectively promote the development of the personality of students. Moral behavior education is the formation of moral actions and moral habits. The act characterizes the attitude of man to the surrounding reality. Moral habit is the need to commit moral actions. Habits based on the rules of the behavioral culture, discipline, and complex when the pupil has a need and willingness to carry out activities that have a specific value. For successful habit formation it is necessary that the motives by which children are encouraged to be meaningful in their eyes, so that the attitude to the implementation of the actions of the children was emotionally positive and that, if necessary, the children were able to show some effort of will to achieve a result. [24]

High spirituality affects by love, kindness, compassion, honesty, justice, mercy, tolerance. The higher the spiritual potential of the person, the more powerful natural defense human body in general. People with a low level of spiritual development do not have a robust immune system.

The primary function of spiritual and moral education is to form a moral consciousness in the younger generation, sustainable moral behavior and moral feelings corresponding to the modern way of life, to form an active life position of each person, a habit to be guided in their actions, actions, relationships, feelings of public duty [25].

Spiritual and moral education has its specific goals. The dominant social relations and spiritual values determine moral education. The purpose of education is the formation of a morally stable integral personality.

The process of moral education is only useful when the teacher has feedback about the effectiveness of educational influences and takes this information into account at each new stage of his pedagogical activity. The teacher receives such information only from life, from the everyday study of the practice of relationships and activities among the educated.

Moral values are the most critical element of the internal structure of personality, which provides and shows the degree of its maturity and sociality, determines the very essence of a social individual, the state of development of the inner world of a person, his mind, character, consciousness, conscience, soul, characterizes his level of humanity.

The process of the personal moral values formation:

1. Moral orientation through the saturation of knowledge, taking into account the age characteristics of the individual. The purpose of this stage is to generate interest in knowledge, to promote the development of moral needs.

2. Through emotions to the realization of the spiritual and moral principles of the personality. The goal is to wake up the emotional sphere.

3. Stimulation of internal reserves of the individual. The goal is the maximum inclusion in the situation of spiritual and moral choice.

4. The actualization of the moral potential of the individual. The goal is to ensure the independence of choice.

5. Stimulation of personal position. The goal is the formation of beliefs.

The content of the process is in the gradual and consistent preparation of thoughts, feelings, and actions of students to spirituality, to the moral-oriented experience of behavior, in the awareness of the conditions for its implementation. 
From the content of the process of forming the moral values of the individual, we see that spiritual and moral needs play a significant role in it.

The concept of "moral need" includes a range of mental phenomena relating to the system of psychological support, peculiar only to human behavior, which the individual himself relates to the public interest [26].

The spiritual and moral needs are the most important psychological component of the moral and motivational behavior of a person. B.D. Parygin [27] and others have established that the formation of two complex psychological phenomena - readiness to act and the ability to act - must precede any human action.

Readiness for a motivated act implies:

a) the desire to act accordingly;

b) the absence of opposing desires or in any case the predominance of the first factor.

The ability to morally act includes some mental qualities in a specific "set" for each moral act and each situation, in addition to knowing how to act. In one case, it is willpower, in the other, courage, in the third, activity, and so on.

On this occasion, B.I. Dadonov writes: "not every person with an altruistic type of general emotional orientation can show high responsiveness, similar to how not all people who dream of a feat can accomplish it. In the type of general emotional orientation, only the need of the individual in the joy of certain experiences is recorded. But not always people are willing to pay for it dearly. " [28] . Thus, the gap between aspirations and real actions is associated with the inability of the individual to the volitional effort. Therefore, when forming a spiritual and moral personality, special attention should be paid to the development of willpower in it [29].

In the studies of psychologists (L.S. Vygotsky [30] , A.N. Leontyev [31] , N.N.Trubnikov [32] and others ) are sensitive and imprinted peaks in personality development. According to their views, in the life of an individual, there are periods most favorable for the formation of certain qualities and abilities, including moral ones. From such views, the role of age periods in the spiritual and moral formation of the personality is determined.

Thus, the formation of mental and personality traits that can influence its behavior begins at the moment of birth and continues throughout life. However, at the same time, it is not possible to form one or another line at will at every age. The formation of individual consciousness can lead at very early stages to the creation of persistent personality traits, rigid behavioral stereotypes, which subsequently can be corrected by tutors and education.

\section{REFERANCES}

[1] The concept of education in the system of continuous education of the Republic of Kazakhstan. Astana, November 16, 2009.

[2] Repina, T. A. Feelings of a Child // Preschool Education. 1961. №1 P. 17-21.

[3] Fridman, LM, Kulagina, I. Yu. A teacher's psychological reference book. M .: education, 1191. 288 p.

[4] Korotov V. M., Shiyanov E.N. Philosophical Foundations in Modern Pedagogy. Rostov-on-Don, 1994.

[5] G. Tuyukina. The creative heritage of V. A. Sukhomlinsky is a scientific and pedagogical basis for increasing the effectiveness of the management of children's reading in the library. Abstract of dis.kand.ped.nauk. M., 1984. 22 p.

[6] Rubinstein S. L. Problems of general psychology. M: Uchpedgiz, 1946.- 457 p.

[7] Zdravomyslov A.G., Yadov V.A. Attitude to work and value orientations of the individual // Sociology in the USSR. T.2. M., 1965. P.189-205.

[8] Schwartz S.H., Bilsky W. Toward and the Journal of Personality and Social Psychology. 1987. Vol.58. № 5. P.550-562.

[9] Leontiev, D.A. Methodology for the Study of Value Orientations. M., 1992, 17 p.

[10] Momov V. Man, morality, education (theoretical and methodological problems): Trans. from bolg. M., 1975.163 p.

[11] Maslow A. Psychology of Being: Trans. From English - M .: Refl-beech; Kiev: Vakler, 1997. 304 p.

[12] Maslow A. Self-actualization // Psychology of personality. Texts / ed. Yu. B. Gippenreiter, A. A. Bubbley. -M.: Publishing House of Moscow State University, 1982. P.208-118.

[13] Frankl V. Man in Search of Meaning: Trans. With English . And him . M .: Pro gress , 1990.-368 with .

[14] Rokeach M. Beliefs, Attitudes, and Values. San Francisco, Josey-Bass Co, 1972. 214 p .

[15] Rokeach M. The nature of human values. NY, Free Press, 1973.

[16] V. Zaslavsky (1993) 'Success and collapse: Traditional Soviet nationality policy', in I. Bremmer and R. Taras (eds.) Nations and Politics in the Soviet Successor States.Cambridge: Cambridge University Press, 29-42.

[17] Titarenko A.I. Structures of moral consciousness. M., 1974.

[18] Yadov V.A. Regulation and self-regulation of social behavior of an individual: problem statement // Self-regulation and prediction of social behavior of an individual. M., 1979. p. 6-32.

[19] Skvortsov L.V. The subject of history and social identity. M., 1983 
[20] Godecek J. Value orientation of the personality // Psychology of personality in a socialist society. M., 1989.

[21] Kharlamov, I.F. Pedagogy: studies. Manual / I.F. Kharlamov. 2nd ed., Pererab. And add. M .: Higher School, 1990. 576 p.

[22] E. Fromm. To be or to have.

[23] N. M. Borytko "The system of professional education in high school" Teaching manual. Moscow, 2005. 119c.

[24] Ushinsky K.D. "On the moral element in education" // Ushinsky KD. Collected Works: At 11 vols. T. 2. Pedagogical articles. 1857-1861 M.L., 1948. p. 425.

[25] ibid.

[26] Rubinstein S.L. Fundamentals of general psychology. M., 1946. 356 p.

[27] Parygin B.D. Fundamentals of socio-psychological theory. M., 1971. 120 p.

[28] Dadonov B.I. Emotional orientation and personality traits // Questions of psychology. 1974. №6.

[29] Pervomaysky B.L. On the typological basis of the structure of personality // "Problems of the personality". Symposium materials. M., 1956. V. 1. 460s.

[30] L.S. Vygotsky. Selected psychological studies. M., 1956. 460s.

[31] Leontiev A.N. Selected psychological works. In 2 volumes. M., 1983. 725s.

[32] N.N. Trubnikov. Science and morality. M., 1990.

\title{
А.А. Карабалина ${ }^{1}$, А. Б. Альситова ${ }^{2}$, Ж.Н. Кереймаганбетова ${ }^{1}$, Н. М. Абишева ${ }^{3}$ \\ ${ }^{1}$ Қ.Жұбанов атындағы Ақтөбе өңірлік мемлекеттік университетінің; \\ ${ }^{2}$ С.Бәйішев атындағы Ақтөбе университеті; \\ 3 «Өрлеу» БАҰО» АҚ филиалының Ақтөбе облысы бойынша ПҚБАИ \\ ҚҰНДЫЛЫК - РУХАНИ-АДАМГЕРШІЛІК БІЛІМ БЕРУ НЕГІЗІ
}

Аннотация. Қазақстан Республикасының білім беру жүйесі бірқатар реформалардан өтуде. Көптеген шешілмеген мәселелер әлі де бар. Бұл мәселелер жас ұрпақтың рухани-адамгершілік тәрбиесін де қамтиды. Бұл мәселенің туындауы рухани вакуум пайда болғандағы (ұлттық мәдениетке зорлық-зомбылықтың енуі, эгоизм, алдау, батыстық коммерциялық мәдениет және т.б.) идеологиялық бағыттардың өзгеруімен байланысты.

Руханияттың жетіспеушілігі, төмен мораль, сондай-ақ дөрекілік, қылмыс, нашақорлық, маскүнемдік және біздің заманымыздың көптеген басқа да зұлымдықтары - олардың бәрі адамды, қоғамды және мемлекетті бұзады. Қазіргі уақытта «Руханилық», «адамгершілік», «эмоционалдық және моральдық сезімдер» ұғымдарының теориялық тұжырымдамалары көбінесе түсіністік және келіспеушілікпен жиі сипатталады, алдымен соны түсініп алу керек. Қазіргі заманғы күрделі кезеңде, қажетті моральдық қасиеттерді қалыптастыруға әрқашан оң әсер етпейтін бұқаралық ақпарат құралдарының ағымында жас ұрпаққа шындық пен жалғандықты анықтау қиынға соғуда. Рухани-адамгершілік тәрбиенің негізгі түсініктері мен факторларының мәні бойынша біздің көзқарасымыз жаңа идеяларды іздестірудің негізгі тұжырымдамаларына негізделген.

Түйін сөздер: рухани-адамгершілік тәрбие, адамгершілік, адамгершілік қасиеттер, адамның рухани құндылықтары.

УДК 316,625

\author{
А.А. Карабалина ${ }^{1}$, А. Б. Альситова ${ }^{2}$, Ж.Н. Кереймаганбетова ${ }^{1}$, Н. М. Абишева ${ }^{3}$ \\ ${ }^{1}$ Актюбинский региональный государственный университет им. К. Жубанова; \\ 2 Университет Баишева, Актобе, Казахстан; \\ ${ }^{3}$ АО «НЦПК «Өрлеу» ИПК ПР по Актюбинской области, Актобе, Казахстан
}

\section{ЦЕННОСТЬ КАК БАЗОВАЯ ОСНОВА ДУХОВНО-НРАВСТВЕННОГО ОБРАЗОВАНИЯ}

Аннотация. Система образования Республики Казахстан переживает ряд реформ. Остаются нерешенные многие проблемы. К таким проблемам можно отнести духовно-нравственное воспитание подрастающего поколения. Постановка этой проблемы связана со сменой идеологических ориентаций, в появлении духовного вакуума (проникновение в национальную культуру культа насилия, эгоизма, обмана, западной коммерческой культуры и т.д.). Бездуховность, низкая нравственность, а также грубость, преступность, наркомания, алкоголизм и многие другие пороки нашего времени - все они разрушают как человека, общество, так и государство. Необходимо сразу пояснить, что в настоящее время теоретические разработки понятий «духовность», «нравственность», «эмоционально-нравственные чувства» отличаются зачастую неясностью и противоречивостью. В сложной современной действительности, в потоке средств массовой информации, которые далеко не всегда оказывают положительное воздействие на формирование необходимых нравственных качеств, молодому поколению становится все труднее разобраться - что для него истинно, а что ложно. Наши взгляды на сущность основных понятий и факторы развития духовно-нравственного воспитания опираются на ключевые понятия для поиска новых идей.

Ключевые слова: духовно-нравственное воспитания, нравственность, нравственные качества, нравственные ценности личности.

Information about authors:

Karabalina Aksaule Alipkaliyevna - candidate of psychological sciences, associated professor of K. Zhubanov ARSU;

Kereimaganbetova Zhanara - senior lecturer, master of social knowledge, ARSU.K. Zhubanov ;

Assemgul Alsitova - Aktobe University named after S. Baishev, Senior Lecturer of faculty of Pedagogics of Preschool education and upbringing department, Master of Pedagogical Sciences, assemgul_87@mail.ru 


\section{МАЗМҰНЫ}

Беспаева Р.С., Бугубаева Р.О., Мануэль Ф. Грела2. Көрсеткіштердің теңдестірілген жүйесі негізінде Щучинск-Бурабай курорттық аймағын дамытудың кешенді стратегиясын қалыптастыру ................................................................................ 5

Аюпова 3.К., Құсайынов Д.Ө.Азаматтық процесстерді жетілдірудегі интеграцияның кейбір қырлары...................... 13

Құсайынова А. А., Вальдемар Козловски, Геращенко И. П.Қазақстан республикасындағы міндетті әлеуметтік сақтандырудың қаржылық-құқықтық тетіктерінің ерекшеліктері.

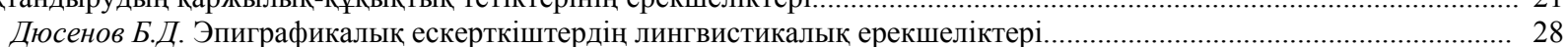

Джумадилова Ш.Г., Атабай Б.Ж. Қазақстандағы халықтың жинақтарының динамикасы......................................... 33

Карабалина А.А., Альситова А. Б., Кереймаганбетова Ж.Н., Абишева Н. М. Құндылық - рухани-адамгершілік

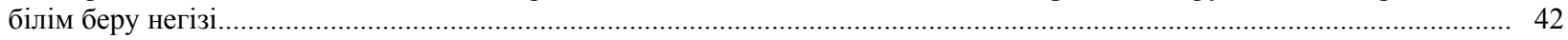

Кенжебаева Д.К., Өрмөрза Б. Ғ., Дашгин Махаммадли. Қазақстандық заманауи жастардың құндылығы............. 51

Нурманова А.Ш., Медерова Д.Е., Дюсенов Б.Д. «Бөкейхан әулетінің талдыбейіт қорымы» эпиграфикалық ескерткіштері тарихи дереккөз ретінде.

Кыдырова Ж.Ш., Онласынов Е.З., Абишова А.У., Шадиева А.А. Оңтүстік Қазақстан облысы сүт және сүт өнімдері нарығындағы жағдайды зерттеу ......

Абимова Г.У., Аманжолов Р., Мынбаева Б.Н., Ибрагимова Д.И. ЖОО-да биолог-студенттердің жобаларды

ұйымдастырылуы мен орындалуына даярлығы.......

Балтабаева А.Ю., Ризаходжаева Г. Мәдени интеграция үдерісіндегі жібек жолының феномені............................... 9

Бурганова Р.И., Абдугалина С.Е., Туякова А.Е. Студенттерге бағытталған білім беру арқылы білім сапасын

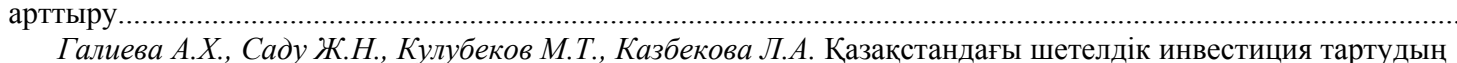

институционалдық жағдайын (талаптарын) бағалау..

Джалилов 3.Г., Батырхан Б.Ш. ХX ғ. екінші жартысындағы шетелдік исламтанушылардың ислам және саясат

туралы теориялық дискурсы.......

Джумабекова А.Т., Канатова А.Ж. Қаржылық ынтымақтастық жағдайларындағы Қазақстан республикасының

ұлттық банкінің өткізу механизмінің өзгеруі......

Дүйсен Г. М., Айтжанова Д. А. Қазақстан және Орталық Азия елдеріндегі көші-қон процесстері дамуының мәселелері мен ерекшеліктері

Есендұлова М.Н. Қазақстандағы « Қиын балаларды» оңалтудың және әлеуметтендірудің психологиялық ерекшеліктері

Жакишева К.М., Жуманова Д.Т., Мукашева Г.М. Экономиканың аграрлық секторының тұрақты дамуына арналған ауыл шаруашылық кәсіпорындарының қаржылық шарттарын мониторингінің рөлі.....

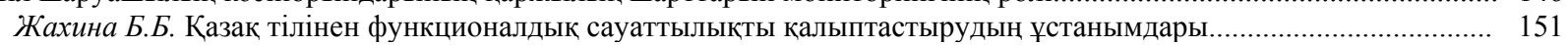

Идресова У.Х., Садуахасова 3.Ж., Муханова А.Т. Криминалистика....................................................................... 156

Савельева В. В. Қазақстандағы кредит технологиясын пайдалану және дамуының тарихи және педагогикалық базасы.

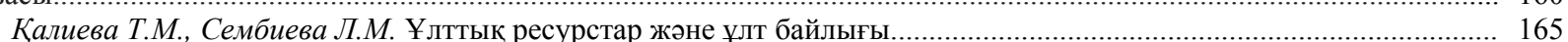

Каримова Р.У., Хаджиева Г.У. ҚХР Ұлттық саясаты контексіндегі ШҰАА-ның этносаяси және әлеуметтікэкономикалық трансформациясы мәселесі.

Керімбек Г., Молдашбаева Л., Джрауова Қ., Ажмухамедова А., Мизанова А. Қазақстан республикасының

республикалық бюджетіне түсетін салық түсімдерінің көрсеткіштерін талдау және бағалау.....

Жолдасбекова С.А., Парманкулова П.Ж., Асаналиев М.К. Мүмкіндігі шектеулі балаларды дамытудағы ұлттық ойындар

Молдакенова Е.К., Байгабулова К.К., Онаева Б.Т. БҚО-да инновациялық үрдістерді басқарудың аймақтық

аспектілігі жүйесінің дамудың жолдары.

Мұратова Г.К., Шаушенова А.Г., Жумасеитова С.Д., Онұварбаева М.Б.Білім беру үрдісінде бұлттық

технологияларын қолдану......

Несіпбеков E. Н., Аппакова Г.Н. Кәсіпорынның инвестициялық портфелін қалыптастырудың теориялық

Нургабылов М.Н., Барлыков Е.К., Егембердиева С.М. ҚР есеп өнеркәсібінің дамуының басқаруының трендсі....... 220

Нурымбетов Т.Я., Абишова А.У., Уразбаева Г.Ж., Кыдырова Ж.Ш., Байнеева П.Т., Абишо Н.У. Модернизациялық

жағдайындағы қр халқын әлеуметтік қолдауының басымдықтары.....

Рахимова С. А., Тургумбекова М. М. Қазақстан республикасындағы шағын және орта бизнестіңмемлекеттік қолдау

бағдарламалары және олардың тиімділігін жүзеге асыру шаралары.......................................................................... 233

Руденко Е.И. Орталық пен Оңтүстік Азия мемлекеттері арасындағы ұғынудың бұрмалануы - «Жұмсақ күш»

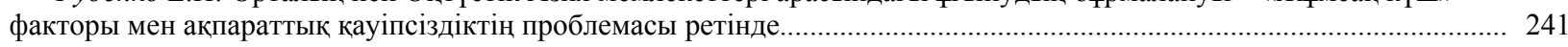

Тохтабаева Ш. Қазына-сандық.......................................................................................................... 251

Утепкалиева К.М., Сабирова Р.К., Кенбаева Г.У. Мұнай-газ секторындағы мемлекеттік-жеке серіктестікті дамыту

Мыңбаев Д. Е. Банкте басқару есебін ұйымдастыру тұжырымдамасы...

Султанова Г.С. Жаңа формацияның экономисі - бакалаврдың кәсіби құзыреттілігін қалыптастырудың

Шаяхметова А.А. Университет жағдайында инклюзивті білім беру үшін педагогтарды оқыту....... 


\section{СОДЕРЖАНИЕ}

Беспаева Р.С., Бугубаев Р.О., Мануэль Ф. Грела. Формирование комплексной стратегии развития ЩучинскоБоровской курортной зоны на основе сбалансированной системы показателей. Аюпова 3.К., Кусаинов Д.У., Уинстон Наган. Некоторые грани интеграции в совершенствовании гражданского процесса.

Кусаинова А.А., Козловски Вальдемар, Геращенко И.П. Обзор некоторых особенностей финансово-правового механизма обязательного социального страхования в республике Казахстан......

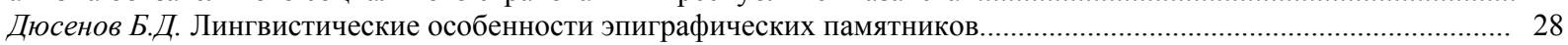

Джумадилова Ш.Г., Атабай Б.Ж.Динамика сбережений населения в Казахстане................................................... 33

Карабалина А.А., Альситова А. Б., Кереймаганбетова Ж.Н., Абишева Н. М. Ценность как базовая основа духовнонравственного образования.

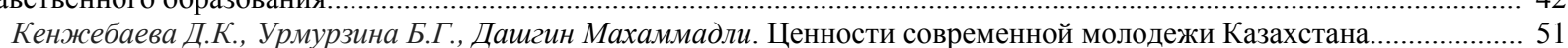

Нурманова А.Ш., Медерова Д.Е., Дюсенов Б.Д. Эпиграфические памятники «Некрополи талдыбейит династии

Бокейхановых» как исторический источник.

Кыдырова Ж.Ш., Онласынов Е.З., Абишова А.У., Шадиева А.А.Исследование ситуации на рынке молока и молочной продукции южно-казахстанской области

Абишова Г.У., Аманжолов Р., Мынбаева Б.Н., Ибрагимова Д.И. Готовность студентов-биологов к организации

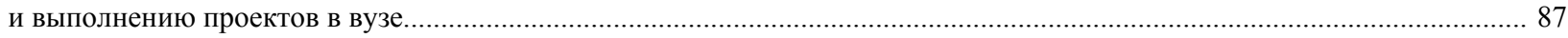

Балтабаева А.Ю., Ризаходжаева Г. Феномен великого шелкового пути в процессе культурной интеграции............... 91

Бурганова Р.И., Абдугалина С.Е., Туякова А.Е. Повышение качества образования посредством

студентоцентрированного обучения...

Галиева А.Х., Саду Ж.Н., Кулубеков М.Т., Казбекова Л.А. Оценка институциональных условий привлечения

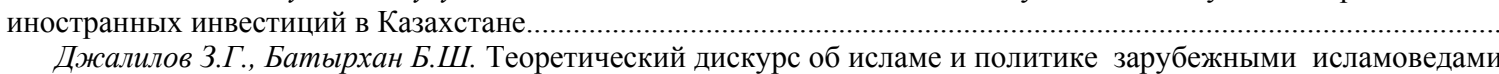
второй половины ХX в.

Джумабекова А.Т., Канатова А.Ж. Трансформация трансмиссионного механизма национального банка республики

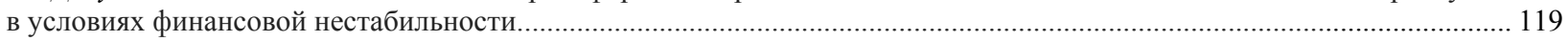

Дуйсен Г.М., Айтжанова Д.А. Проблемы и особенности развития миграционных процессов в Казахстане

и странах Центральной Азии.

Есенгулова М.Н. Психологические особенности реабилитации и социализации "Трудных подростков"

в Казахстане".

Жакишева К.М., Жуманова Д.Т., Мукашева Г.М.Роль мониторинга финансового состояния сельскохозяйственных

предприятий в обеспечении устойчивого развития аграрного сектора экономики.........................................................146

Жахина Б.Б. Принципы формирования функциональной грамотности казахского языка.......................................... 151

Идресова У.Х., Садуахасова 3.Ж., Муханова А.Т. Криминалистика......................................................................... 156

Савельева B.B. Исторические и педагогические основы формирования и разработки кредитной технологии

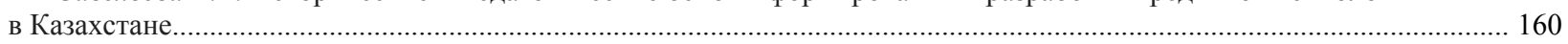

Калиева Т.М., Сембиева Л.М. Национальные ресурсы и богатство нации.................................................. 165

Каримова Р.У., Хаджиева Г.У. К вопросу об этно-политической и социально-экономической трансформации

СУАР в контексте национальной политики КНР

Керимбек Г., Молдашбаева Л., Джрауова Қ., Ажмухамедова А., Мизанова А. Анализ и оценка показателей

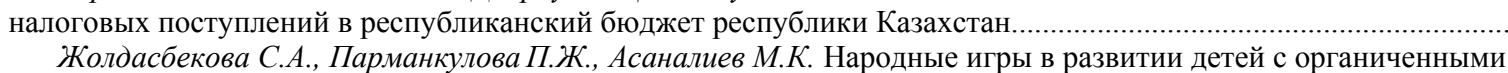

Жолдасбекова С.А., Парманкулова П.Ж., Асаналиев М.К. Народные игры в развитии детей с органиченными

Молдакенова Е.К., Байгабулова К.К., Онаева Б.Т.Пути развития системы регионального аспекта управления

инновационными процессами в АПК.

Муратова Г.К., Шаушенова А.Г., Жумасеитова С.Д., Онгарбаева М.Б. Применение облачных технологий

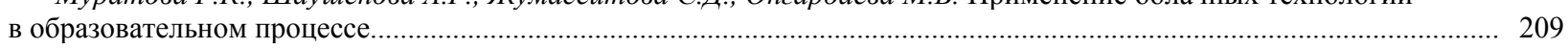

Несипбеков Е.Н., Аппакова Г.Н. Теоретические аспекты формирования инвестиционного портфеля предприятия. 214

Нургабылов М.Н., Барлыков Е.К., Егембердиева С.M. Тенденции управления развитием мясоперерабаты-

вающей отрасли в РК.

Нурымбетов Т.Я., Абишова А.У., Уразбаева Г.Ж., Кыдырова Ж.Ш., Байнеева П.Т., Абишов Н.У. Приоритеты

социальной поддержки населения РК в условиях модернизации................................................................................. 22

Рахимова С. А., Тургумбекова М. М. Программы государственной поддержки мсб в республике Казахстан и меры

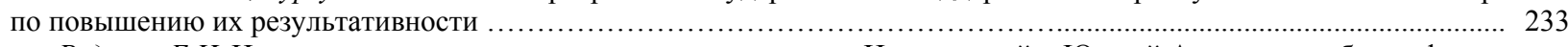

Руденко Е.И. Искаженность восприятия между государствами Центральной и Южной Азии как проблема фактора

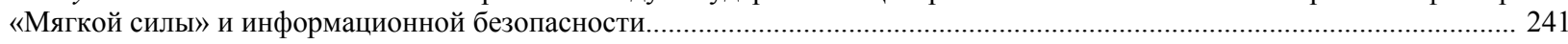

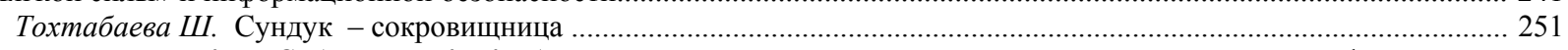

Утепкалиева К.М., Сабирова Р.К., Кенбаева Г.У.Развитие государственно-частного партнерства в нефтегазовой

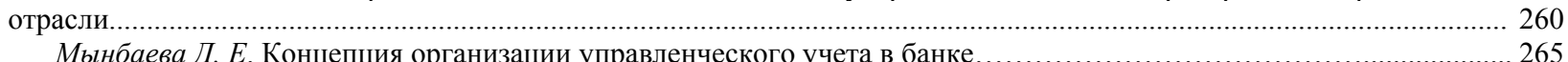

Мынбаева Д. Е. Концепция организации управленческого учета в банке...........................................2.
Султанова Г.С. Педагогические аспекты формирования профессиональных компетенций бакалавра - экономиста

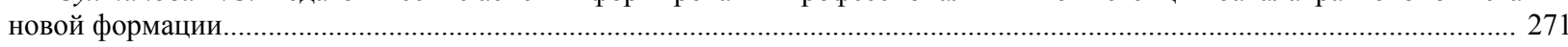

Шаяхметова А.А. О подготовке педагогических кадров к инклюзивному образованию в условиях вуза................ 277 


\section{CONTENTS}

Bespayeva R.S., Bugubayeva R.O., Manuel F. Grela. Formation of the complex strategy for development of the Schuchinsk-

Burabay resort area based on the balanced system of indicators.

Ayupova Z.K., Kussainov D.U., Winston Nagan. Some facets of integration in themodernization ofthe civil process..............13

Kussainova A.A., Kozlowski Waldemar, Gerashchenko I.P. The review of some features of the financial legal mechanism of obligatory social insurance in the republic of Kazakhstan...

Dyussenov B.D. Linguistic features of epigraphic monuments................................................................................ 28

Jumadilova Sh.G., Atabay B.Zh. Dynamics of the population savings in Kazakhstan.......................................................... 33

Karabalina A.A., Alsitova A.B., Kereimaganbetova Zh.N., Abisheva N.M. The values as critical factor of moral education... 42

Kenzhebayeva D.K., Urmurzina B.G., Dashqin Mahammadli. The modern youth values in Kazakhstan............................. 51

Nurmanova A.S., Mederova D.E., Dyussenov B.D. "Bokeykhanov dynasty taldybeyit necropolis" epigraphic monuments

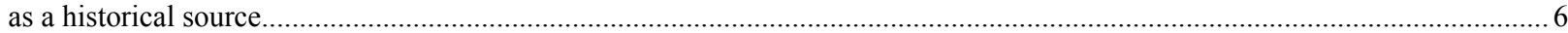

Kydyrova Zh.Sh., Onlasynov E.Z., Abishova A.U., Shadieva A.A.Research of the situation in the market of milk and dairy

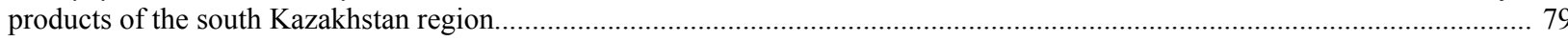

Abishova G.U., Amanzholov R.A., Mynbayeva B.N., Ibragimova D.I. Readiness of students-biologists for the organization

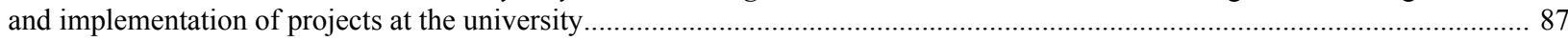

Baltabayeva A.Y., Rizakhojayeva $G$. The phenomenon of the great silk road in the cultural integration process................... 91

Burganova R.I., Abdugalina S.E., Tuyakova A.E. Improving the quality of education through student-centered education... 102

Galiyeva A.Kh., Sadu Zh.N., Kulubekov M.T., Kazbekova L.A. Assessment of the institutional terms of the foreign

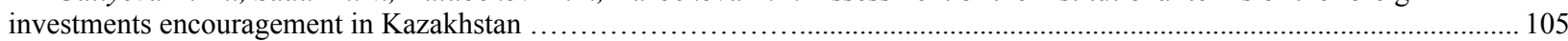

Dzhalilov Z.G. Theoretical discourse on islam and politics in foreign humanism of the second half of 20th century.......... 112

Dzhumabekova A.T., Kanatova A.ZH. Transformation of the transmission mechanism of the national bank of the republic

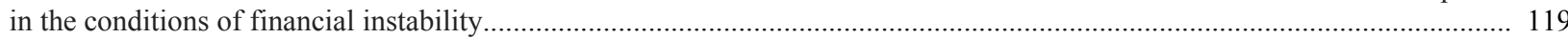

Suleimenov R.B. Problems and features of the development of migration processes in Kazakhstan and Central Asia.......... 124

Yesengulova M.N. Psychological aspects of reintegration and resocialization of "Trouble" adolescents in Kazakhstan....... 134

Zhakisheva K.M., Zhumanova D.T., Mukasheva G.M.The role of monitoring the financial condition of agricultural

enterprises in ensuring sustainable development of the agrarian sector of the economy......................................................... 146

Zhakhina B.B. Principles of functional literacy formation of the kazakh language....................................................... 151

Idresova U.Kh., Saduahasova Z.Zh., Mukhanova A.T. Criminalistics............................................................................. 156

Savelyeva $V . V$. Historicalandpedagogical bases of formation and development of credit technology in Kazakhstan........... 160

Kaliyeva T.M., Sembiyeva L.M. National Resources and national wealth.................................................................. 165

Karimova R., Hajiyeva G. Examining ethno-political and SOCIO-economic transformation of the xinjiang uyghur

autonomous region in the context of the PRC national policies........................................................................................ 176

Kerimbek G., Moldashbayeva L., Jrauova K., Azhmukhamedova A., Misanova A. Analysis and evaluation of reduction

of tax recovery of the republic of kazakhstan on the budget of the republic of Kazakhstan................................................. 185

Zholdasbekova S.A., Parmankulova P.Zh., Assanaliyev M.K. Folk games in the education of children with physical, mental and sensory disturbances..

Moldakenova E.K., Baygabulova K.K., Onaeva B.T. Ways of development of the system of the regional aspect of managing innovative processes in the APC.

Muratova G.K., Shaushenova A.G., Zhumassseitova C.D., Ongarbayeva M.B. Application of cloud technologies in the educational process......

Nurgabylov M.N., Barlikov E.K., Egemberdieva S.M. Trends of management of the development of meat processing industry in RK

Nurymbetov T.Ya., Abishova A.U., Urazbaeva G.Zh., Kydyrova Z.Sh., Baineeva P.T., Abishov N.U. Priorities of social support of the population of republic of Kazakhstan in the conditions of modernization........

Rakhimova S. A., Turgumbekova M. M. Programs of government support for sme in the republic of Kazakhstan and measures to enhance their efficiency.....

Rudenko Ye.I. Misperception between the states of Central and South Asia as a 'Soft power' and information security issue...

Tokhtabayeva Sh. Zh. Treasure-chest.

Utepkalieva K.M., Sabirova R.K., Kenbaeva G.U.Development of public private partnership approach in oil and gas

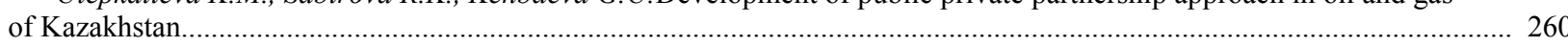

Mynbayeva D.E. Concept of organization of management accounting in bank ........................................................... 265

Sultanova G. S. Pedagogical aspects of formation of professional competence of the bachelor-economist of the new formation

Shayakhmetova A.A. On the training of teaching staff for inclusive education under the conditions of higher education institution. 


\section{PUBLICATION ETHICS AND PUBLICATION MALPRACTICE IN THE JOURNALS OF THE NATIONAL ACADEMY OF SCIENCES OF THE REPUBLIC OF KAZAKHSTAN}

For information on Ethics in publishing and Ethical guidelines for journal publication see http://www.elsevier.com/publishingethics and http://www.elsevier.com/journal-authors/ethics.

Submission of an article to the National Academy of Sciences of the Republic of Kazakhstan implies that the work described has not been published previously (except in the form of an abstract or as part of a published lecture or academic thesis or as an electronic preprint, see $\mathrm{http} / / / \mathrm{www} . e l s e v i e r . c o m / p o s t i n g p o l i c y)$, that it is not under consideration for publication elsewhere, that its publication is approved by all authors and tacitly or explicitly by the responsible authorities where the work was carried out, and that, if accepted, it will not be published elsewhere in the same form, in English or in any other language, including electronically without the written consent of the copyrightholder. In particular, translations into English of papers already published in another language are not accepted.

No other forms of scientific misconduct are allowed, such as plagiarism, falsification, fraudulent data, incorrect interpretation of other works, incorrect citations, etc. The National Academy of Sciences of the Republic of Kazakhstan follows the Code of Conduct of the Committee on Publication Ethics (COPE), and follows the COPE Flowcharts for Resolving Cases of Suspected Misconduct (http://publicationethics.org/files/u2/New_Code.pdf). To verify originality, your article may be checked by the originality detection service Cross Check http://www.elsevier.com/editors/plagdetect.

The authors are obliged to participate in peer review process and be ready to provide corrections, clarifications, retractions and apologies when needed. All authors of a paper should have significantly contributed to the research.

The reviewers should provide objective judgments and should point out relevant published works which are not yet cited. Reviewed articles should be treated confidentially. The reviewers will be chosen in such a way that there is no conflict of interests with respect to the research, the authors and/or the research funders.

The editors have complete responsibility and authority to reject or accept a paper, and they will only accept a paper when reasonably certain. They will preserve anonymity of reviewers and promote publication of corrections, clarifications, retractions and apologies when needed. The acceptance of a paper automatically implies the copyright transfer to the National Academy of sciences of the Republic of Kazakhstan.

The Editorial Board of the National Academy of sciences of the Republic of Kazakhstan will monitor and safeguard publishing ethics. 
Правила оформления статьи для публикации в журнале смотреть на сайте:

\section{www:nauka-nanrk.kz}

\section{social-human.kz}

Редакторы М.С. Ахметова, Т.А. Апендиев, Д.С. Аленов

Верстка на компьютере А.М. Кульгинбаевой

Подписано в печать 08.12.2018

Формат 60x881/8. Бумага офсетная. Печать - ризограф.

17,7 п.л. Тираж 500. Заказ 6.

Национальная академия наук $Р К$

050010, Алматы, ул. Шевченко, 28, т. 272-13-18, 272-13-19 